\title{
$\mathrm{RC}$ 造建築物の外壁・屋上防水 仕様における耐久性に関する意 識調査
}

\section{AN ATTITUDE SURVEY ON DURABILITY OF EXTERIOR WALL AND ROOFING SPECIFICATIONS OF REINFORCED CONCRETE BUILDINGS}

\begin{tabular}{|c|c|}
\hline 長谷川拓哉 一 $* 1$ & 井戸川純子 —* \\
\hline 久保孝昭 一*1 & 植木暁司 — $* 2$ \\
\hline
\end{tabular}

キーワード

耐久性, 目的指向, 意識調查, 実務者

Keywords:

Durability, Objective-based, Attitude survey, Engineer

$\begin{array}{ll}\text { Takuya HASEGAWA }-* 1 & \text { Junko IDOGAWA }-* 2 \\ \text { Takaaki OHKUBO }-* 1 & \text { Kyoji UEKI } \\ \text { Kumiko ONO } & \text { Takaya KOJIMA }-* 1\end{array}$

The purpose of this study is establishing the objective-based durability design method for building components. Herein the objective-based design means that selecting the most appropriate specification of building components according to the each requested performance level of durability. In this paper, it is reported the attitude survey on durability of $\mathrm{RC}$ building components for building engineers. According to the results, the most engineers consider that it should be selected the appropriate specification of building components according to the conditions such as region, direction, parts of buildings.
1.はじめに

近年、品確法をはじめとして建築物のユーザー保護の施策が展開 されているが、建築物の耐久性について、ユーザーニーズに応じた 性能を実現する仕様を選定する技術は、未だ確立されていないのが 現状である。そのため、本研究では建築物の耐久性に関するユーザ 一からの要求レベルに応じ、適切な建築材料·部材の仕様を決定し、 適切な施工、維持管理に係る情報管理を一貫して行う目的指向型耐 久設計を害現させるための支援ツールを開発することを目的として いる 1)。本稿ではその一環として、建設プロジェクトに携わる実務 者が、 R C 造建築物の屋上防水及び外壁の具体的仕様を選定する際、 而扻性に関してどのような意識をもっているのかを明らがするこ とを目的としアンケート調查を行った結果を報告する。

\section{2. アンケート調査概要}

アンケート調查は、平成 14 年 2 月から 3 月にかけて、建設プロ ジェクトに携わる実務者を対象に行っている。アンケート送付数は 490 通で、そのうち回答者数は 188 名（回答率 $38 \%$ ) である。回答 者業種内訳と回答者属性を表 1 に示す。なお、集計は回答者属性別 に行っている。アンケート調査の内容は、中層 RC造集合住宅の一 般外壁及び屋上防水に使用する材料構工法を選ぶ場合について、各 部位に考慮すべき性能とそのうち経年変化する性能、その具体的各 仕様の寿命がきたと考える理由、劣化が早いと考えられる条件（方 位、部位、地域、施工によるばらつきの差、地域による品質の差、 条件によって劣化が異なる場合仕様を変更すべきかどうかについて、 調查を行っている。このアンケートでは、各性能の定義は表 2 に示
す通りとしている。なお、ここでいう耐久性とは、「建築物及びこれ を構成する材料・部材のある性能が時間が経過しても維持される性 質」と定義している。

表 1 回答者業者内訳と回答者属性（複数回答の場合有り）

\begin{tabular}{|c|c|c|c|}
\hline 回答者業種 & & 回答者属性 & 人 \\
\hline 設計事務所 & & 企画·計画 & 21 \\
\hline 総合請負業 & 86 & 意匠設計 & 20 \\
\hline 専門工事業 & 25 & 構造設計 & 19 \\
\hline 材料メ一力一 & 25 & 工事監理 & 11 \\
\hline ハウスメーカー & & 工事計画·施工管理 & 23 \\
\hline 官公庁 & 15 & 専鹠工事 & 15 \\
\hline 複数業種 & 9 & 材料製造·販売 & 18 \\
\hline その他 & 10 & 研究開発 & 52 \\
\hline \multicolumn{3}{|c|}{ その他 } & 32 \\
\hline
\end{tabular}

表2 各性能の定義

\begin{tabular}{|c|}
\hline 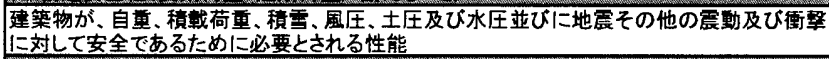 \\
\hline (5) J \\
\hline $\begin{array}{l}\text { モルタル、タイルおよび澵装、その他の仕上材が剥䧺または落下しないために必要とされる } \\
\text { 性能 }\end{array}$ \\
\hline (c) 1 (b) \\
\hline 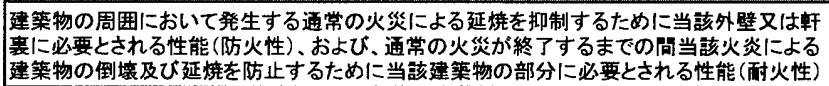 \\
\hline 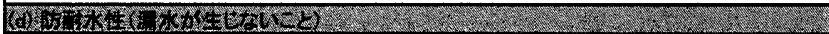 \\
\hline 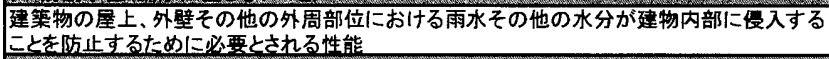 \\
\hline 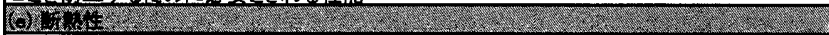 \\
\hline 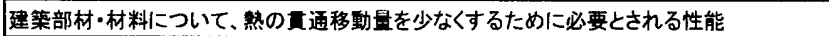 \\
\hline 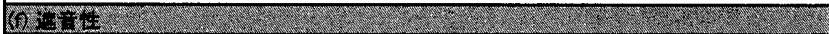 \\
\hline $\begin{array}{l}\text { 陪する住戸からの日常生活に伴い生ずる音を皘神衛生上支障がない程度に低娍するた } \\
\text { ぬ界壁に必要とされる性能 }\end{array}$ \\
\hline 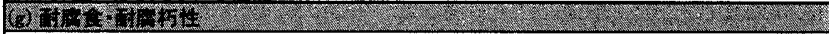 \\
\hline 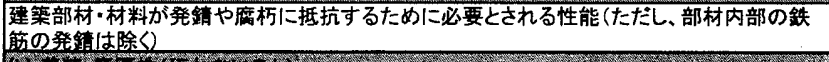 \\
\hline 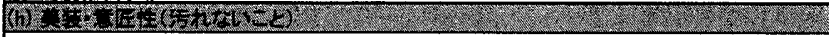 \\
\hline 建築部材・材料の見た目が变化することに抵抗するために必要とされる性能 \\
\hline
\end{tabular}

*1 Building Research Institute

*2 National Institute for Land and Infrastructure Management, MLIT 


\section{3. アンケート調查結果}

\section{1 外壁及び屋上防水の仕様巽定時に考虑する性能}

一般外壁を構成寸る材料や仕様を選ぶ場合、通常優先的に考慮 する性能または条件についての回答を図 1 に示す。設問は上位 1 位から5位までを回答いただく形式とし、図の緹軸は、1位 $=5$ 点、 5 位 $=1$ 点として集計した值の全体に対する百分率を示して いる。この図加全体の傾向として、構造安全性、而剥離・剥落 性、防耐水性及び美装・意匠性が優先的に考虑されていることが わかる。また、重要度の傾向は、回答者属性によって異なってお り、意匠設計及び材料・製造であれば美装・意匠性、構造設計及 び工事監理では構造安全性が優先的に考慮するという回答の傾向 が示されている。

経年変化を重視する性能についての回答者全体の結果を図 2 に 示す。これより、図1で優先的に考慮するとしてあげられている 構造安全性、耐剥離・剥落性、防耐水性及ひ美装・意匠性汪経年 変化を「極めて重視する、又は「重視する」という回答が多い。 このことから、外壁の仕様選定を考虑する場合、これらの性能の 経年変化の考慮は重要であるといえる。

同样に屋上防水を構成する材料や仕样を選ぶ場合、通常優先的 に考慮する性能または条件についての結果を図3に示す。屋上防 水については、防耐水性分優先的に考慮されており、施工容易性、 メンテナンス容易性、材料構工法の信頼性の回答が多、傾向とな っている。経年変化を重視する性能についての回答者全体の結果 を図4に示す。これから防耐水性について経年変化を「極めて重 視する」、重視する」という回答が多く、またこれらのことから、 屋上防水については当然のことながら、防耐水性が最む重要であ り、経年変化についてもこの点が重視されていると考えられる。

\section{2 各仕様の寿命がきたと考えられる年数とその理由}

次に具体的な外壁仕樣及び防水仕样を対象とした耐久性に関す る意識をアンケートした結果を示す。調査の対象の仕様を表 3 に 示す。な㧍、パネル仕上げについては、様々な材質のパネルを想 定し、材質も記述していただく形式としていたが、ほとんどの回 答がアルミニウムパネルであったため、以下、パネル仕上げにつ いては、アルミニウムパネルとして扱うものとする。

各仕様における” 寿命がきた” と考えられる年数の最短と最長 を図 5 に示す。これは既存文献の調査結果 233) とほぼ一致する回答

\section{表3 調査で例示した外壁仕上げ仕様及び防水仕様}

\begin{tabular}{|c|c|c|c|}
\hline & & & \\
\hline モルタル哈り仕上げ & モルタル & $\begin{array}{l}\text { アスファルト防 } \\
\text { 水層路出 }\end{array}$ & $\begin{array}{l}\text { Pスファルト防水露 } \\
\text { 出 }\end{array}$ \\
\hline $\begin{array}{l}\text { 合成澍脂エマルションペイント䣽り } \\
\text { 仕上げ }\end{array}$ & EP & $\begin{array}{l}\text { アスファルト防水層 } \\
\text { コンクリート押さえ }\end{array}$ & $\begin{array}{l}\text { アスファルト防水コン } \\
\text { 沙ート押え }\end{array}$ \\
\hline $\begin{array}{l}\text { 外装合成樹脂エマルション系薄付 } \\
\text { け仕上䇠仕上げ(樹脂リシン) }\end{array}$ & 薄淕E & $\begin{array}{l}\text { 改買アスファルトシ- } \\
\text { トーチエ法路出 }\end{array}$ & Fーチ \\
\hline $\begin{array}{l}\text { 合成澍脂エマルション系複層仕上 } \\
\text { げ梁材仕上げ(アクリルタタル) }\end{array}$ & 複層E & ゴムシート防水 & ゴムシート \\
\hline $\begin{array}{l}\text { 反応硬化形合成澍脂エマルション } \\
\text { 系複層仕上げ整材仕上げ(水系エ } \\
\text { ポキシタイル) }\end{array}$ & 複層RE & 塩ビシート防水 & 塩ビシート \\
\hline タイル張り仕上げ(湿式·手張りエ & タイル手張 & ウレタン鉒膜防 & ウレタン淮膜 \\
\hline タイル張り仕上げ(湿式·先付けエ & タイル先付 & スデルスシート防水 & ステンレスシーート \\
\hline タイル張り仕上げ(乾式工法) & タイル乾式 & & \\
\hline パネル仕上げ & パネル & & \\
\hline
\end{tabular}

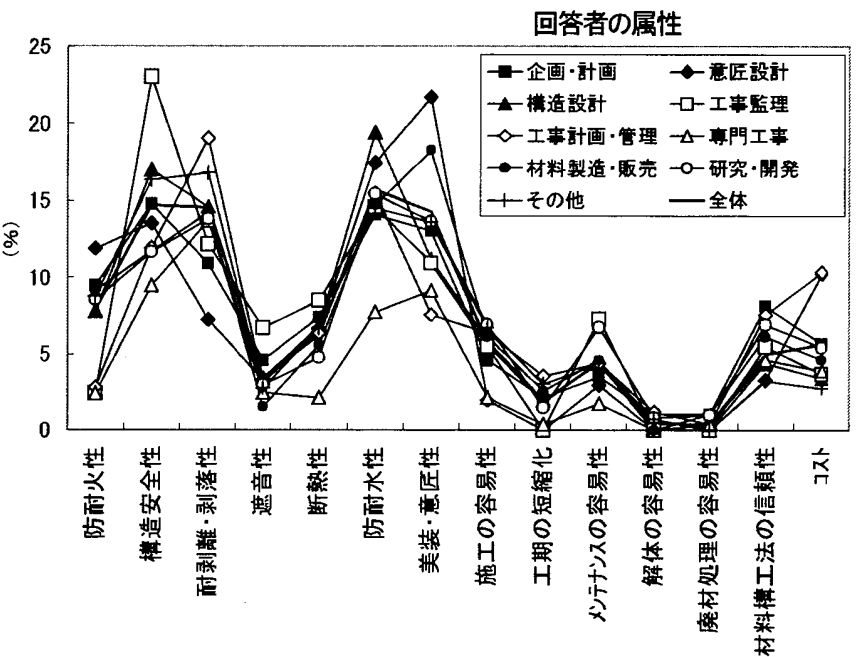

図1一般外壁の仕梯選定時に二優先的に考虑する性能·条件

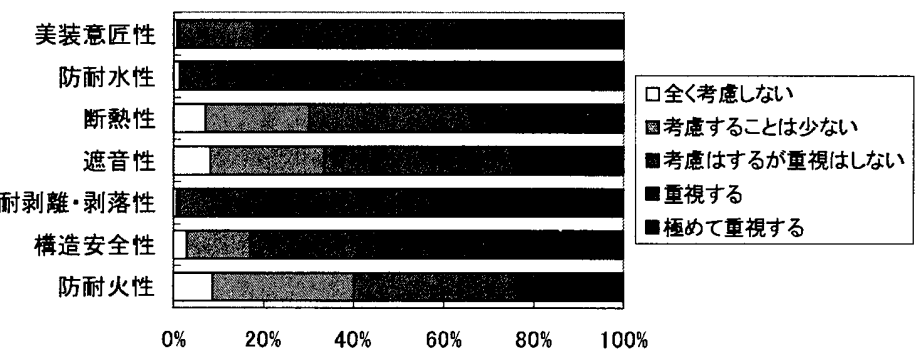

図2一般外壁の仕様選定時|経年変化を重視する性能

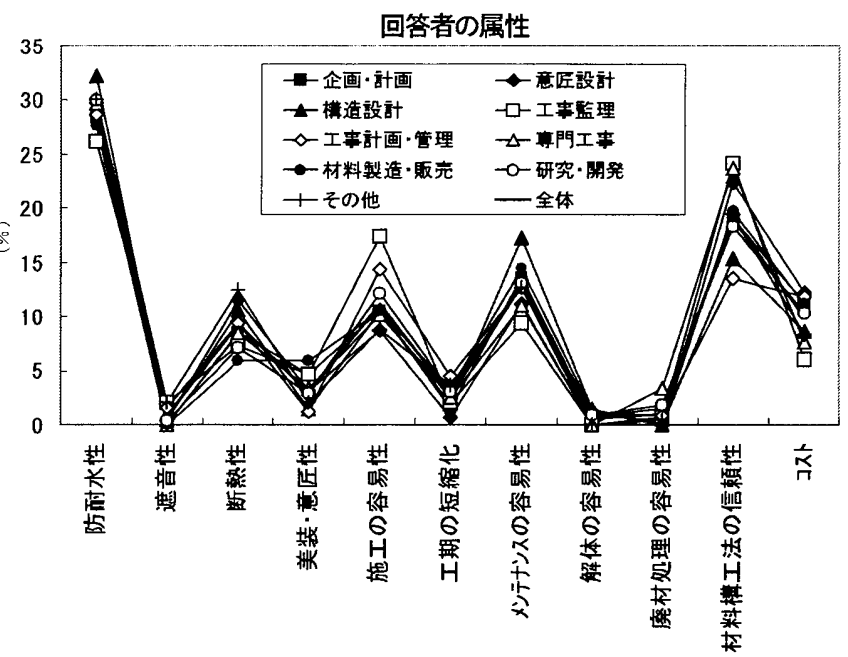

図3屋上防水の仕様巽定時に優先的に考虑する性能·条件

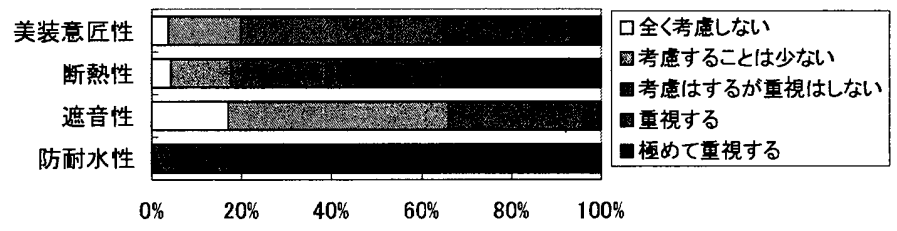

図4屋上防水の仕様選定時にこ経年変化を重視する性能 


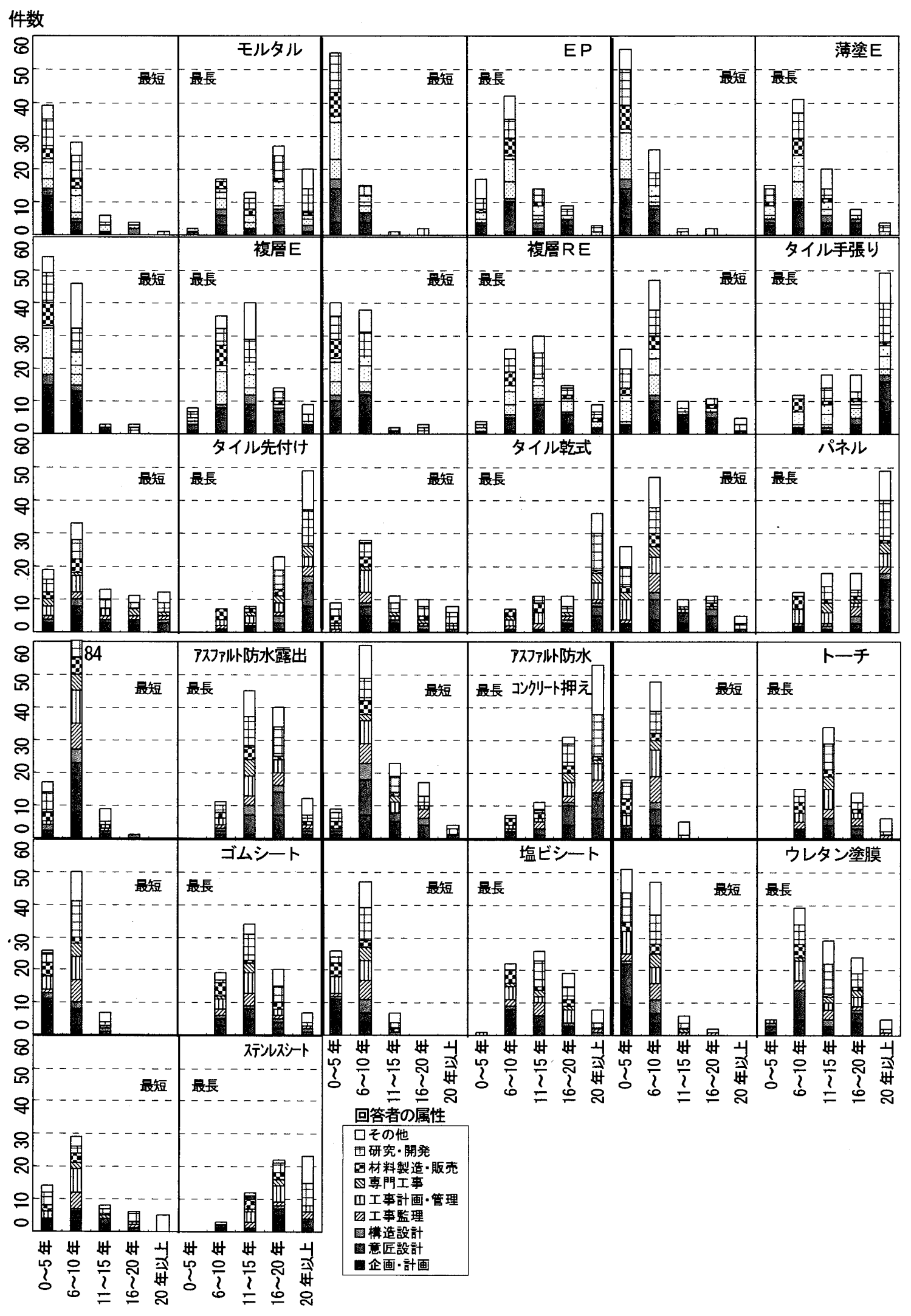

図5 各仕様における寿命がきたと考える年数の最短及び最長 
が得られている。タイルの各仕様（手張り、先付け、乾式 以下、

「タイル系」と呼称) では、寿命とする年数が異なることが予想さ れたが、結果では全て最短を 6 年〜 10 年、最長を 20 年以上とす る回答が多い。これから、実務者にとって、タイルの寿命はその工 法によらず同じようにとらえられていると考えられる。

各仕様で”寿命がきた”と考える理由について、外壁仕様の代表

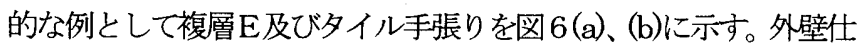
様については、塗材系とモルタル、タイル系では傾向が異なる。塗 材系は「劣化のため最初にあった性能が維持できないため」という 回答が多く、モルタル及びタイル系では「劣化のため危険な状況と なったため」という回答が多い。これから塗材系では、美装・意匠 性等が損なわれた場合を寿命として想定しており、モルタル及びタ イル系では剥離・剥落を寿命として想定していると考えられる。

防水仕样の代表例としてアスファルト防水露出を図 $6(\mathrm{c})$ に示す。 防水仕様では全ての仕様で「劣化のため最初にあった性能が維持で きないため」という回答が多く、これは防耐水性が損なわれた場合 を寿命として捉えていると考えられる。

3.3 各仕様の少化が早いと考えられる方位、部位、地域の差

劣化が早いと考えられる方位について、外壁仕様に関する回答を
図7に示す。塗材系は、南、次いで西の回答が多い。この結果は、 既存文献の調查結果とも一致している 4)。またタイル手張りは、 南と西の回答が多い。ただし、方位の差はないという回答数も多く、 実務者によって認識がわかれていると考えられる。タイル先付けと タイル乾式では、方位による差がないという回答が多くなっている。 その他の仕様は明確な傾向が見いだせなかった。

劣化が早いと思われる部位の差については、外壁仕様における回 答では、塗材系はほほ同様の傾向を示している。代表的なものとし て複層 $\mathrm{E}$ の結果を図8(a)に示す。一般外壁、斜壁、外壁空まわり、 ひさし鼻先、パラペットの劣化が早いという回答が多い。これに対 し、モルタル及びタイル系については開口部迴りが最も回答数が多 く、ひさし鼻先、斜壁、一般外壁の回答が多い。代表的な仕様とし てタイル手張りの結果を図8(b)に示す。これはモルタル、タイル等 はひひ割れがその主な劣化として捉えられ、塗材系は污れが主な劣 化として捉えられていると考えられる。防水仕様における回答では、 全てパラペット、防水層、笠木部分の回答が多くなっている。

また、アスファルト防水露出、アスファルト防水コンクリート押 え、塩ビシート、ウレタン塗膜に関して劣化が早いと思われる部位 の結果を図9(a)、(b)に示卞。アスファルト防水コンクリート押えは
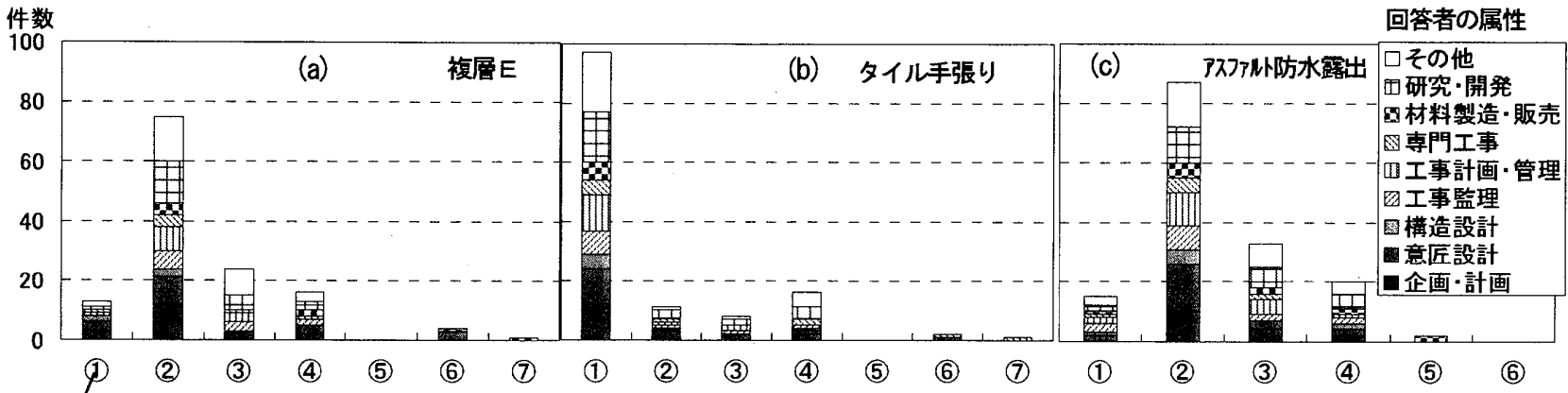

理由 : (1)劣化のため危険な状況となったため (2)劣化のため最初にあった性能が維持できないため（3)性能が判断時の一般的なしべルに比べ低くなっている ため (4)補修のコストかかかり過ぎるため (5)法規制に適合しなくなったため 66その他

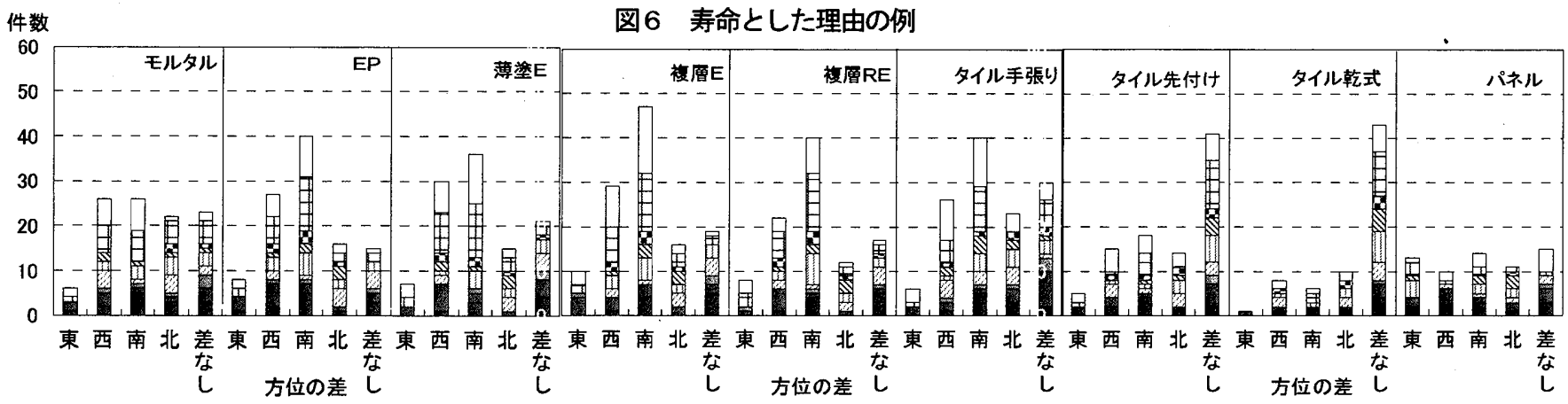

図7劣化が早いと思われる方位 (凡例は図6参照)

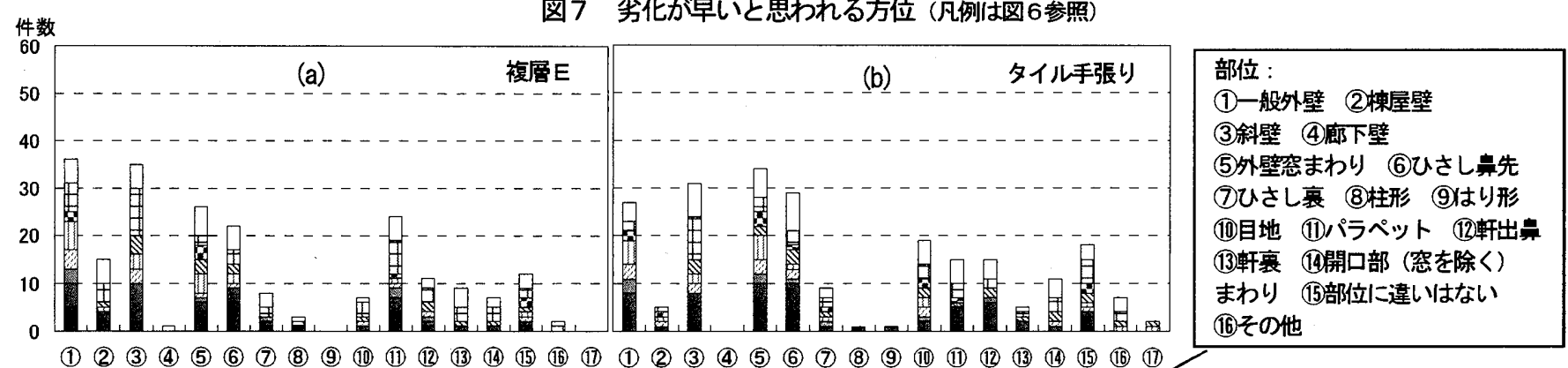

図8 劣化が早いと思われる部位（外壁仕様の例）(凡例は図6参照) 
防水押えが最も劣化が早いと考えられていることがわかる。

劣化が早いと思われる地域の差についての回答を図 10 に示す。 外壁仕様において塗材系は全て同様の傾向であり、日射の影響が強 い地域、寒冷地域、海岸地域が劣化しやすいという回答が多い結果 となっている。これらの仕様は、熱劣化、柴外線劣化が主な劣化と してあげられることと、今回の調査では仕上げを行う下地はR C 造 であるため、その劣化が大きくなる可能性のある寒冷地域、海岸地 域があげられていると考えられる。一方、モルタル、タイル系につ いては寒冷地域が劣化しやすいという回答が多くなっており、これ らの仕様は寒冷地における凍結融解等の劣化が大きな問題と捉えら れていると考えられる。タイル手張りについては、日射の影響が強 い地域も回答数が多く、日射による影響が大きいと捉えられている と考えられる。防水仕様においては、全ての仕様で寒冷地域、暑熱
地域の回答が多く、アスファルト防水コンクリート押え及びステン レスシートを除き、日射の影響が強い地域の回答が多くあげられて いる。これは各仕様の使用材料に応じており、高分子材料であれば、 熱劣化、柴外線劣化が主な劣化としてあげられるためと考えられる。 3.4 施工が高度で品質にばらつきが生じる仕様及び地域によって 入手できる材料に差がある仕様

施工が高度で品質にばらつきが生じるおそれがあると考えられる ものに関する回答を図 11 及ひ図 12 に示す。外壁仕様について、、 タイル手張り、モルタル、タイル先付けのばらつきが大きいという 回答が多くなっている。これらは専門の職人の腕による部分が大き い工法であるためと考えられる。また、防水仕様について、どの 仕様についてもばらつきが生じるおうそれがあるという回答となって いるが、アスファルト防水層コンクリート押え及びアスファルト防

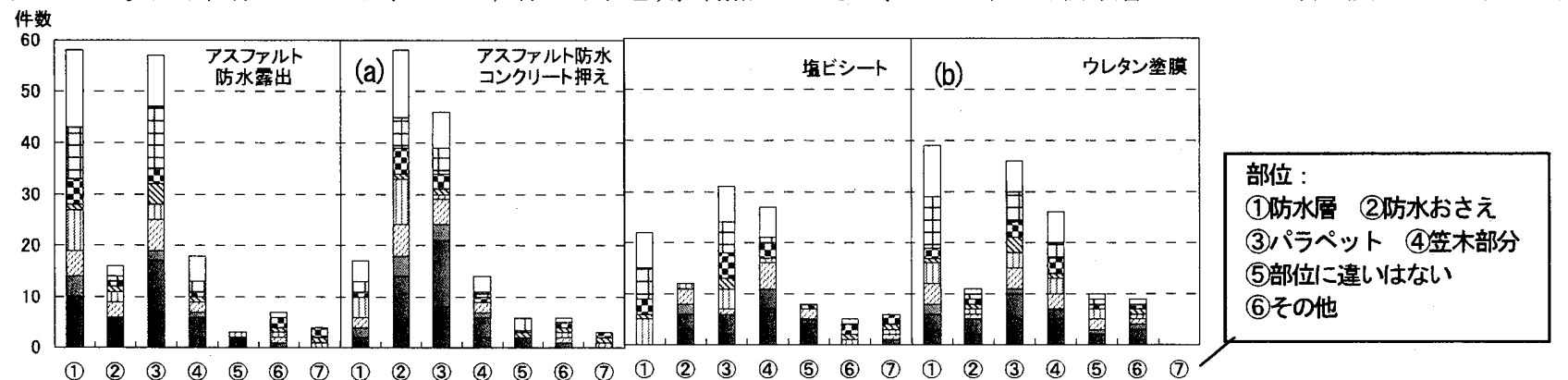

図9 劣化が早いと思われる部位（防水仕様の例）(凡例は図 10 参照)

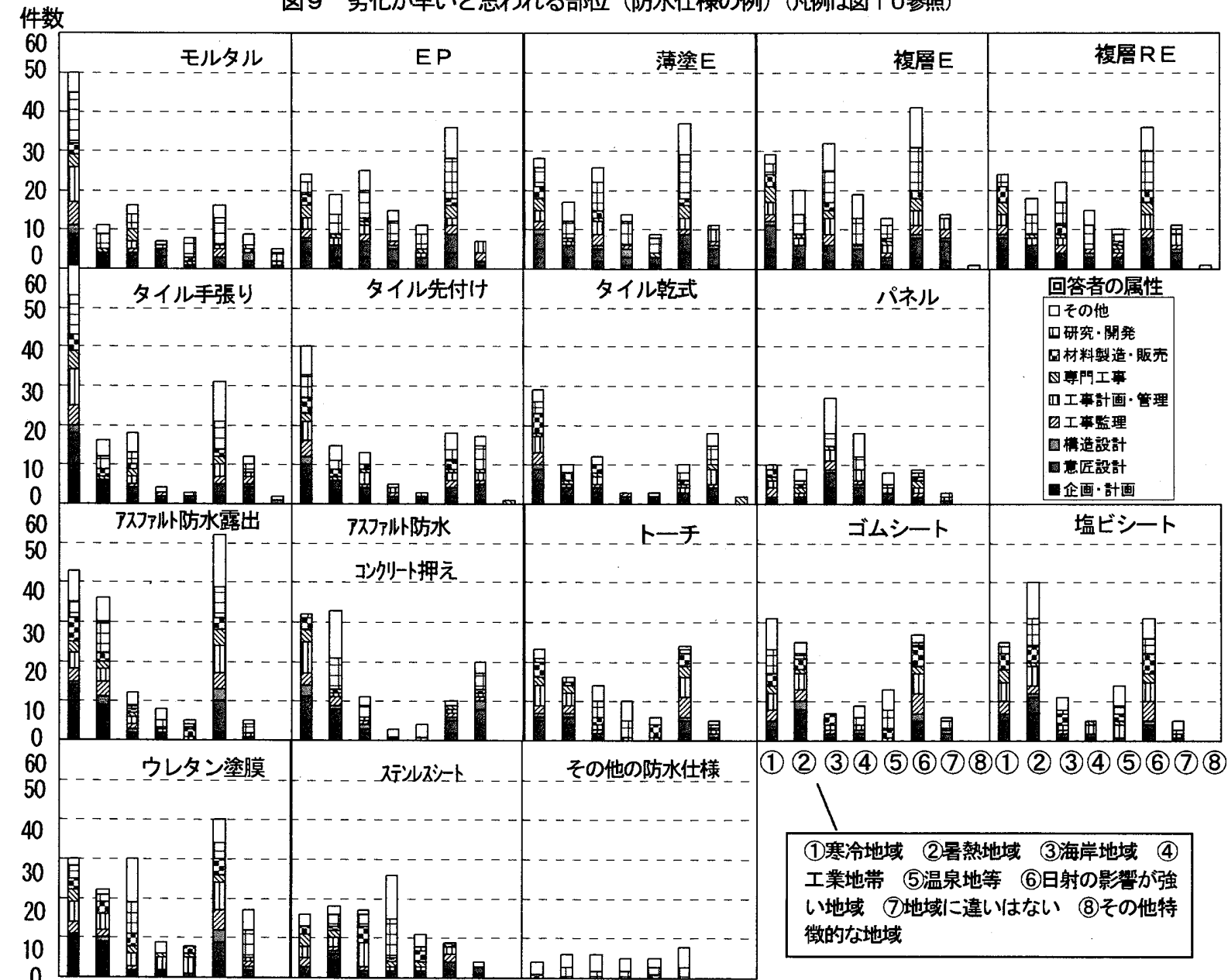

(1) (2) (3) (4) (5) (6) (7) (8) (1) (2) (3) (4) (5) (6) (7) (8)(1) (2) (3) (4) (5) (6) (7) (8)

図 10 劣化が早いと思われる地域（外壁仕様及び防水仕様） 
水層露出については、他仕様に比べるとばらつきが生じるおうそれが あるという回答が少ない結果となっている。これは、比較的昔から ある工法で、実績によるものと考えられる。

地域によって入手できる材料の品質に差があるものに関する回答 を図 13 及ひ図 14 に示す。これから外壁仕様については、モルタ ルの回答が多く、次いで夕イル手張りであった。これは、モルタル に使用する骨材が地域によって異なるためと考えられる。防水仕様 については全般に回答数が少なく、明確な傾向は見いだせなかった。

\section{5 仕様を変えるべきと考える条件}

設計において仕样を变えるべきと考える条件に関する回答を図 15 及び図 16 に示す。これから、外壁仕様、防水仕様ともに地域、 部位、外壁仕様については方位により変えるべきという回答が多く、 条件で仕様を変えることは不要とする回答を上回る結果となった。 このことから実務者の意識としては、地域、部位、方位によって仕 様を変える必要がある場合があると考えているといえる。しかし、 地域、部位、方位に応じて仕样を適切に変える技術メニューは未整 備と考えられ、ユーザーニーズに応じた適切な仕样を選定するため には、この点に適切に対応する技術開発が今後の課題と考えられる。

\section{4. まとめ}

実務者を対象に、RC造建築物の外壁及び屋上防水の仕様に関す る耐久性の意識調查をアンケート調查により行った。その結果、実 務者の意識に関して、次の実態の把握ができた。

1)外壁の要求性能としては、構造安全性、耐剥離・剥落性、防耐水 性及び美装・意匠性、屋上防水の要求性能としては、防而水性を重 視する実務者が多く、これらの性能はその技術を選択するに際し、 経年変化を重視する実務者が多い。

2)外壁仕椂の寿命としては、塗材では性能（美装・意匠性等）が維 持できなくなった時点、タイル及びモルタルでは剥離・录落による 安全性の低下した時点、屋上防水では性能（防耐水性等）が維持で
きなくなった時点とする実務者が多い。

3)方位別の劣化では、塗材では西及び南とする実務者が多い。 4)外壁仕様における部位別の劣化では、塗材では一般外壁、斜壁、 外壁空まわり、ひさし鼻先、パラペット、モルタル及びタイルでは 開口部迴り、ひさし鼻先、斜壁、一般外壁とする実務者が多いま た、防水仕様における部位別の劣化では、パラペット、防水層、笠 木部分とする実務者が多い。

5)外壁仕様における地域別の劣化では、塗材では日射の影響が強い 地域、寒冷地域、海岸地域、モルタル及びタイルでは寒冷地域、日 射の影響が強、地域とする実務者が多い。

6)実務者は、地域、部位、方位によって仕様を変えるべき必要があ る場合があると考えている。

以上の結果をふまえ、今後、目的指向型耐久設計を実現させるた めの主たる研究対象の検討を行うことを考えている。

謝辞 本研究は (財) 建材試験センター内に設置された「建築部材 の目的指向型耐久設計委員会」(委員長:三橋博三 東北大学大学院 教授）において検討が進められたものです。ここに記し、委員各位 に梁く感謝の意を表します。

\section{参考文献}

1）井戸川純子ほか、建筑部材の目的指向型耐久設計に関する研究 その 1 基本的若 え力およひ設計手法の概要、2001 年建築学会大会梗概集、2001.9、pp649650

2）例えば、建設大臣官房官宁営䋨部監修、(財) 保全センター、改訊建筑物のライフサ イクルコスト、（財）経済調查会、2000.5、pp331-334、pp342-350

3）建設大臣官房技術調查室監修、(財) 国土開発技術研究七ンタ一編、外装仕上げの耐 久性向上技術，技報堂出版、1987.3、pp83-84

4）例之ば、今泉勝吉、渡边敬三、榆木堯、本橋健司、矢野瑞穗「外装㓌仕上材の劣化 䛦断技術に関する調查・研究（その 3$)$ 小1983 年建築学会大会梗概集、1983.9、 pp523-524,

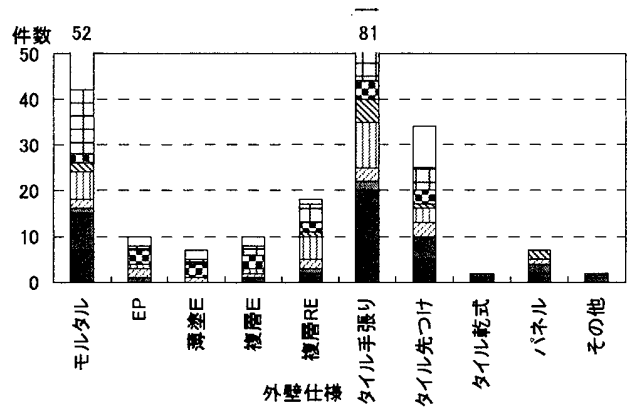

図11 ばらつきが大きいと思われる仕様 （外壁仕様）(凡例は図 15 参照）

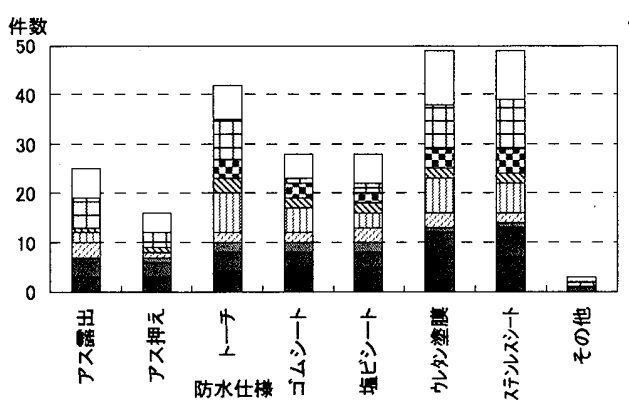

図12 ばらつきが大きいと思われる仕様 (防水仕様)（凡例は図 15 参照）
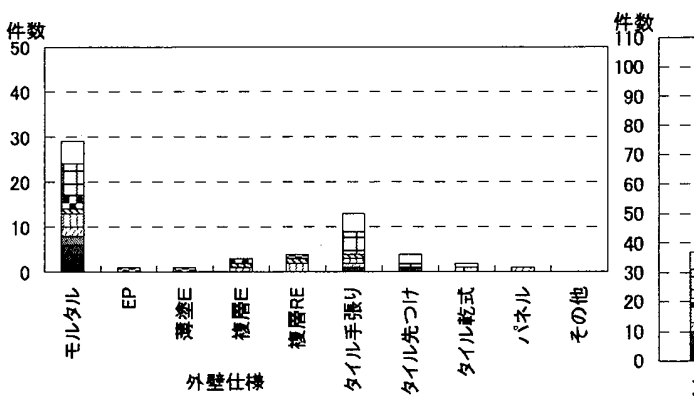

図 13 地域により入手できる材料に差がある 図15 仕様を変えるべきと思われる条件
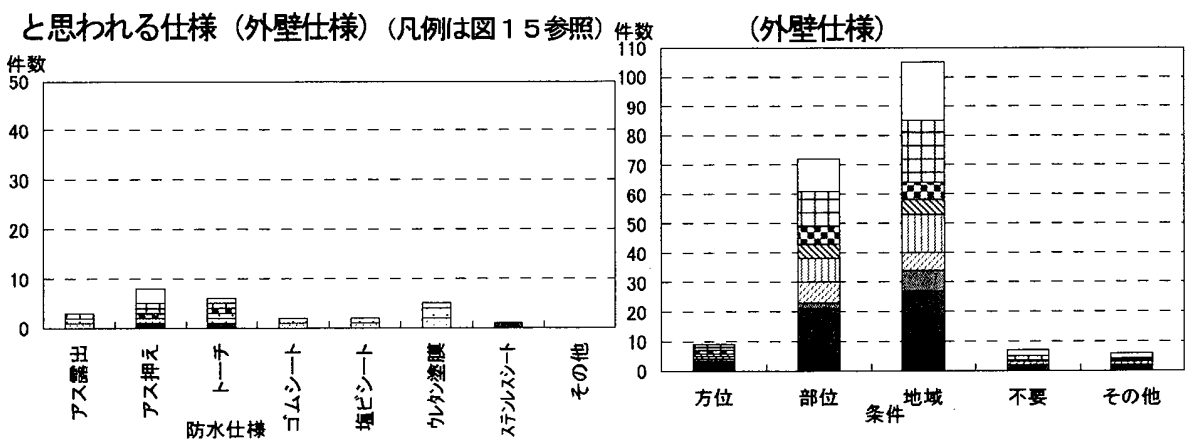

図 14 地域により入手できる材料に差がある 図16 仕様を変えるべきと思われる条件 と思われる仕様（防水仕様）(凡例㘬 15 参照）
回答者の属性

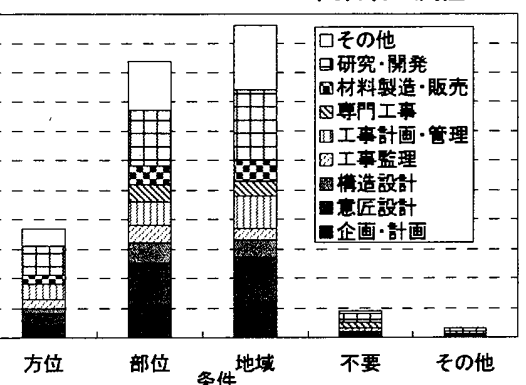
と思われる仕様（外壁仕様）(凡例は図15参照）件数（外壁仕様)

（防水仕様）（凡例は図15参照）

[2002年10月 18 日原稿受理 2003年 2 月25日採用決定］ 